\title{
Hypersplenism in liver disease and SLE revisited: current evidence supports an active rather than passive process
}

\author{
John M. Gemery ${ }^{1,2^{*}}$, Andrew R. Forauer ${ }^{2}$, Anne M. Silas ${ }^{2}$ and Eric K. Hoffer ${ }^{2}$
}

\begin{abstract}
Background: Active and passive theories have been advanced to explain splenomegaly and cytopenias in liver disease. Dameshek proposed active downregulation of hematopoiesis. Doan proposed passive trapping of blood components in a spleen enlarged by portal hypertension. Recent findings do not support a passive process.

Discussion: Cytopenias and splenomegaly in both liver disease and systemic lupus erythematosus (SLE) poorly correlate with portal hypertension, and likely reflect an active process allocating stem cell resources in response to injury. Organ injury is repaired partly by bone-marrow-derived stem cells. Signaling would thus be needed to allocate resources between repair and routine marrow activities, hematologic and bone production. Granulocyte-colony stimulating factor (G-CSF) may play a central role: mobilizing stem cells, increasing spleen size and downregulating bone production. Serum G-CSF rises with liver injury, and is elevated in chronic liver disease and SLE. Signaling, not sequestration, likely accounts for splenomegaly and osteopenia in liver disease and SLE. The downregulation of a non-repair use of stem cells, bone production, suggests that repair efforts are prioritized. Other non-repair uses might be downregulated, namely hematologic production, as Dameshek proposed.
\end{abstract}

Summary: Recognition that an active process may exist to allocate stem-cell resources would provide new approaches to diagnosis and treatment of cytopenias in liver disease, SLE and potentially other illnesses.

Keywords: Hypersplenism, Liver disease, Systemic lupus erythematosus, SLE, Hematopoiesis, Cytopenias, Splenomegaly, Stem cells, Doan, Dameshek

\section{Background}

In the 1940s and 1950s there were two competing theories to account for the coexistence of cytopenias and splenomegaly. Charles Doan proposed a passive process, splenic sequestration, whereby increased portal pressure causes an enlarged spleen that traps blood components, creating cytopenias. William Dameshek postulated an active process, in which a signal, possibly produced by the spleen, downregulated hematopoiesis $[1,2]$. Doan's theory became dominant as early as the 1960s, and even Dameshek is alleged to have said, "Well, it looks as though Charley Doan is right" [3].

\footnotetext{
* Correspondence: John.M.Gemery@Hitchcock.org

'Division of Interventional Radiology, Department of Radiology,

Dartmouth-Hitchcock Medical Center, One Medical Center Drive, Lebanon, $\mathrm{NH}$ 03766, USA

${ }^{2}$ Geisel School of Medicine at Dartmouth, One Rope Ferry Road, Hanover, NH 03755, USA
}

(c) 2016 Gemery et al. Open Access This article is distributed under the terms of the Creative Commons Attribution 4.0 International License (http://creativecommons.org/licenses/by/4.0/), which permits unrestricted use, distribution, and reproduction in any medium, provided you give appropriate credit to the original author(s) and the source, provide a link to the Creative Commons license, and indicate if changes were made. The Creative Commons Public Domain Dedication waiver (http://creativecommons.org/publicdomain/zero/1.0/) applies to the data made available in this article, unless otherwise stated.
In light of current knowledge, Dameshek may have conceded too soon. At least in liver disease and systemic lupus erythematosus (SLE), splenomegaly and cytopenias are poorly correlated with portal hypertension, and there is evidence for downregulation of hematopoiesis, as Dameshek suggested. Splenomegaly and cytopenias, at least to some degree, likely reflect an active process that mobilizes bone marrow stem cells and allocates their distribution among competing demands in response to injury.

\section{Discussion}

Active and passive theories: signaling or sequestration? The theory of hypersplenism is based on the idea of splenic sequestration. Liver damage impedes portal venous inflow, causing elevated portal venous pressure and, in theory, an enlarged spleen. The enlarged spleen is alleged to sequester blood components, causing cytopenias. 
The theory thus accounts for both the splenomegaly and cytopenias found in association with liver disease [4].

Portal hypertension leading to splenic enlargement and sequestration is not, however, a clean explanation of the cytopenias associated with liver disease. Despite the suggested causal relation, spleen size does not correlate with portal pressure [5]. Furthermore, enlargement of the spleen alone may not be sufficient to create cytopenias. For example, pharmacologically increasing the size of the spleen does not result in a corresponding decline in platelet count $[6,7]$.

A patent surgical splenorenal shunt or a transjugular intrahepatic portosystemic shunt (TIPS) will reduce portal venous pressure, yet will neither resolve pre-existing cytopenias nor prevent the development of new cytopenias $[8,9]$. This lack of response could still be explained by hypersplenism if spleen size were to become fixed once enlarged, but this does not appear to happen. Both spleen size and thrombocytopenia correct after liver transplantation, but thrombocytopenia may resolve months prior to significant change in spleen size [10]. Hypersplenism has also been advanced to account for splenomegaly and cytopenias in (SLE), yet liver disease and thus portal hypertension are uncommon features of SLE $[11,12]$. In all, there is poor correlation between spleen size, portal hypertension and cytopenias in both liver disease and SLE.

Other factors that potentially contribute to cytopenias in liver disease have been proposed, including insufficient thrombopoietin (TPO) production by the liver, and marrow injury due to hepatitis viruses, alcohol abuse and poor diet [4]. There are, however, confounding observations which cast doubt on these possibilities.

TPO levels in liver disease appear to be variable, and lack of TPO does not suggest a reason for splenomegaly nor for cytopenias other than thrombocytopenia [13-16]. Nutritional optimization does not prevent the development of cytopenias [17]. Viral or alcohol marrow injury does not explain the cytopenias of patients with liver disease due to autoimmune hepatitis or cystic fibrosis [18-21]. Additionally, patients who have cytopenias before liver transplant are usually able to correct those cytopenias after transplant using the same bone marrow [22-24].

\section{G-CSF: an alternative explanation}

An alternative explanation is that splenomegaly in liver disease and SLE is part of a response to increased demand for stem cells needed for organ repair and triggered by a rise in serum G-CSF. G-CSF administration mobilizes stem cells from marrow with a side effect being enlargement of the spleen [6]. Serum G-CSF has been found to rise with liver injury and to be elevated in both liver disease and SLE [25-28].
In addition to splenomegaly and cytopenias, liver disease and SLE are also characterized by the development of osteopenia that is not explained by hypersplenism $[29,30]$. G-CSF, in addition to its effect on stem cell mobilization, also downregulates bone production-and thus potentially provides a unified explanation for splenomegaly and osteopenia [31]. Since increasing spleen size alone does not result at least in thrombocytopenia [6], some additional effect(s) must occur to account for cytopenias.

Downregulation of bone production by the G-CSF mediated process of stem cell mobilization suggests that repair efforts take precedence over the routine marrow activity of bone production. If so, then downregulating hematopoiesis along with bone production would be logical and exactly what Dameshek proposed well before the discovery that bone-marrow-derived stem cells repair damaged organs. Clinical observations and experimental work indicate that bone marrow stem cell resources are finite; thus, allocation between competing uses would be needed.

In the years since Doan's theory superseded Dameshek's, there have been reports of inhibition of bone marrow culture by sera from cytopenic SLE patients and from cirrhotics, as Dameshek had postulated [32, 33]. At the time of their publication, these reports did not, however, lead to a re-evaluation of Dameshek's theory. The finding that offers a logical explanation for hematopoietic downregulation had not yet been made; namely, that bone marrow stem cells contribute to the repair of the liver and other organs.

\section{Repair by stem cells}

The discovery that liver injury is repaired in part by bone-marrow-derived stem cells has shown that in liver injury there is a demand for stem cell resources [34]. Eckersley-Maslin et al., reviewing human and animal studies, noted that both the duration and severity of liver injury were positively correlated with the degree of incorporation of bone-marrow-derived cells into the liver [35]. More severe and chronic liver injury will place more demands on bone marrow stem cell resources.

The mobilization of stem cells from bone marrow involves cytokine signaling including G-CSF. Clinically, GCSF is used to mobilize stem cells to allow collection, via apheresis, of sufficient numbers for bone marrow stem cell transplantation. One of the side effects of G-CSF administration is enlargement of the spleen. The G-CSF dose is limited to minimize the risk of over-enlargement of the spleen and splenic rupture, which is a reported complication [6].

As administered G-CSF communicates demand for stem cells in bone marrow transplant donors, so may endogenous G-CSF in liver injury. Lemoli et al. noted a significant increase in serum G-CSF following liver injury (i.e., both liver resection and hepatic transplantation), with 
a corresponding increase in the number of stem cells in circulation. Non-hepatic abdominal surgery did not show a similar increase in serum G-CSF [25].

The rise in serum G-CSF does not appear to be restricted to hepatic injury in the form of surgery. Stoiser et al. found significantly increased serum G-CSF in patients with acute malaria who had evidence of concurrent liver injury with elevated serum bilirubin and alanine transaminase (ALT). The effect also does not appear to be limited to acute liver injury [36]. Kaya et al. reported serum G-CSF to be significantly higher in patients with cirrhosis than in normal control subjects, as well as reporting a trend toward higher serum G-CSF levels with increasing Child-Pugh classification [27]. A potentially confounding variable is that all patients studied by Kaya et al. [27] had hepatocellular carcinoma (HCC), which has been reported to produce G-CSF in some instances [37]. Bazarniy et al., however, have also reported increasing serum G-CSF corresponding to worsening Child-Pugh scores in patients with cirrhosis, who were not known to have HCC [28].

Splenomegaly is thus more consistently associated with increased serum G-CSF than with elevated portal venous pressure. G-CSF both mobilizes stem cells and downregulates bone production. Downregulation of bone production, and potentially hematopoiesis, in conjunction with stem cell mobilization would not seem logical unless bone marrow stem cell resources were insufficient to meet all demands simultaneously.

\section{Finite stem cell resources?}

Animal experiments and clinical studies have raised the possibility that bone marrow stem cell resources are finite and that insufficient stem cell resources may manifest as cytopenias. The concept of finite stem cell resources has been incorporated into clinical practice in the timing of chemotherapy and bone marrow stem cell collection for autologous stem cell transplantation. Stem cell mobilization is intended to allow collection of sufficient numbers of stem cells for successful transplantation, but this does not work in all cases. Prior chemotherapy is associated with insufficient stem cell collection, which researchers believe is due to the toxicity of chemotherapy to stem cells $[38,39]$. To minimize the risk of insufficient collection, stem cell mobilization and collection are performed earlier, rather than later, in a course of chemotherapy [38].

In addition to prior chemotherapy, platelet count at the time of mobilization is a significant predictor of stem cell yield, with lower platelet counts associated with insufficient collection [38]. A history of prior chemotherapy and a lower platelet count would appear to convey the same information, namely that there are fewer stem cells available. The cytopenias of liver disease may indicate the same deficiency.

Animal experiments are also consistent with reduced stem cell resources manifesting as cytopenias. Seed et al. studied beagles exposed to gamma radiation for 22 hours per day for life with different groups receiving different exposure rates. Platelet and leucocyte counts declined with initial irradiation, but then plateaued. The higher the daily radiation exposure, the lower the plateaus. Despite the ongoing irradiation, the plateaus were generally maintained over an initial 1,000-day observation period. Erythrocyte counts were more resistant to radiation dose and did not decline in the lower exposure groups but did at higher levels [40].

The pattern suggests a process whereby production of erythrocytes is maintained, in preference to platelets and leucocytes, as marrow resources are diminished. The appearance of cytopenias in liver disease also appears to conserve erythrocyte production in preference to platelets and leucocytes. Qamar et al. found that during follow-up (median 54.9 months), patients with compensated cirrhosis developed thrombocytopenia at a median of 28 months, leucopenia at a median of 30 months and anemia at a median of 39.6 months [41]. The similarity in development of cytopenias between irradiated dogs and cirrhotic humans may reflect the same underlying state, namely insufficient marrow stem cell resources. Whether diminished by radiation or diverted to repair, there appear to be insufficient marrow stem cells to maintain normal hematologic production.

\section{Cytopenias and risk of death}

A similar pattern of mortality in irradiated dogs and cirrhotics is also consistent with diminished stem cell resources in liver disease. In irradiated dogs, the risk of death increased with the degree of cytopenias [40]. In cirrhotic patients, the risk of death also corresponded with the severity of cytopenias. Qamar et al. noted that patients without hematologic abnormalities had a $6 \%$ mortality rate during their study vs. $18 \%$ for those with thrombocytopenia and $28 \%$ for those with both thrombocytopenia and leucopenia [41].

If insufficient stem cell resources result in cytopenias, then we might expect a reduced demand for stem cell resources to allow resumption of normal hematologic production and correction of cytopenias. For example, if freed from the need to support an injured liver, stem cell resources might resume hematologic production. Liver transplantation does reverse pre-transplant cytopenias in most instances, and can do so months prior to any significant decrease in spleen size [10,22]. Of note, cases where there is delay in return to normal hematologic parameters after transplant may occur in patients who had 
poor stem cell resources prior to transplant, and possibly a higher demand for stem cell resources after transplant.

Stanca et al. investigated the persistence of thrombocytopenia after liver transplantation and found that patients with persistent thrombocytopenia had significantly lower platelet counts $(P<.001)$ prior to transplant, and had received livers from older donors $(P<.04)$. No significant differences were noted in recipient age, etiology of liver disease, bilirubin level, international normalized ratio (INR), Mayo end-stage liver disease (MELD) score, United Network for Organ Sharing (UNOS) status, or other donor variables. The lower pre-transplant platelet count suggests, as in autologous stem cell transplant patients, reduced stem cell resources. The older donor livers may require more stem cell support from recipients who are already "stem cell poor" [42].

Observations in patients with liver disease do match those of patients and experimental animals with reduced stem cell resources. If stem cell resources were, in fact, finite, then managing allocation between completing uses would require signaling for allocation between competing demands. Signaling, such as Dameshek proposed, would not be needed in splenic sequestration, as that process would be passive.

\section{Signaling?}

There is direct evidence of in vivo downregulation of a non-repair demand for stem cell resources, namely bone production. Bone abnormalities in patients with liver diseases, termed hepatic osteodystrophy, are well described. In a review article, Luxon noted that osteoporosis is common in patients with disparate liver diseases, that the etiology is poorly understood, and that the prime cause appears to be decreased bone formation rather than increased resorption [29].

Elevated serum G-CSF may provide the explanation, downregulating bone production while mobilizing stem cells for repair efforts. Long-term administration of G-CSF is associated with the development of osteopenia in humans, and causes bone loss in mice [31, 43].

If bone production is downregulated, then other nonrepair uses for stem cells might be as well, namely hematologic production, as Dameshek suggested. Ohki et al. reported that sera from patients with cirrhosis and anemia, when added to cultures of normal marrow, suppressed colony formation of hematopoietic progenitor cells. The degree of suppression correlated with the severity of patient cytopenia. Sera from patients who were cirrhotic but not anemic did not cause suppression [32]. These results were published in 1988, well after Doan's theory superseded Dameshek's, and well before the discovery that bone-marrow-derived stem cells incorporate into the liver. (Note: Ohki's study employed the marrow culture techniques available at the time-using agar as a culture medium-and to date has not been repeated using current bone marrow culture techniques that employ methylcellulose as a culture medium.)

In addition to granulocyte-colony stimulating factor (G-CSF), Interleukin 17 (IL-17) and Interleukin 23 (IL-23) are critical components of stem cell mobilization, at least in mice. Mice with a genetic defect resulting in chronically elevated serum G-CSF display higher than normal numbers of circulating stem cells. Additionally, these mice have high serum levels of IL-17 and IL-23. Antibody blocking of any one of the three cytokines reduces stem cell mobilization [44]. G-CSF, IL-23, and IL17 have all been found to be elevated in diverse liver injuries, consistent with activation of the stem cell mobilization process $[27,28,45-49]$. Blocking or reducing any of the three cytokines may have the same effect in humans as it does in mice, reducing stem cell mobilization.

Splenic embolization has been employed to improve cytopenias in patients with liver disease [50, 51]. The at least partial success of this approach might appear to support the theory of splenic sequestration. The effect may instead be due to altered signaling and provide further support for Dameshek's theory.

In mice, IL-23 is produced in part in the spleen [44]. Splenic embolization in patients with liver disease may in fact be reducing IL-23 production, and thus the mobilization of marrow resources for repair, leaving marrow stem cell resources in place for hematologic production.

The above in combination suggest not the passive process of splenic sequestration promoted by Doan, but rather, the active management of stem cell resources, employing signaling, including the downregulation of hematopoiesis suggested by Dameshek. A management process diverting bone marrow stem cell resources away from hematologic and bone production, and toward hepatic repair, could thus account for splenomegaly, cytopenias and loss of bone mass observed in patients with liver disease.

\section{Systemic Lupus Erythematosus (SLE)}

If there were a mechanism that managed stem cell resources, that mechanism ought to be active not solely in liver disease, but also in other situations where there are competing demands for stem cell resources. Bonemarrow-derived cells can, in fact, incorporate into tissues other than the liver [52], raising the possibility that repair efforts in other disease states could trigger the active allocation of stem cell resources.

With activation of a stem cell allocation mechanism, one might anticipate findings that are due to allocation rather than to the injury that is triggering the allocation process. If the allocation process is active in liver disease, 
then other disease states that activate the same allocation mechanism might share similar findings: namely, splenomegaly; progressive hematologic abnormalities with associated mortality; osteopenia; evidence of stem cell mobilization signaling, such as elevation of serum G-CSF; and possibly suppression of hematopoiesis. We looked for other disease states that have chronic injury and thus might have activation of a stem cell allocation mechanism. Patients with (SLE) suffer chronic multiorgan injury and have findings matching the above $[11,26,30,33,53-55]$.

Hematologic abnormalities are common in patients with SLE, and include anemia, leucopenia and thrombocytopenia [11]. Cytopenias in SLE are associated with greater disease activity and greater mortality, paralleling the increase in mortality with worsening cytopenias reported in patients with liver disease $[41,53,56]$. There are multiple proposed etiologies for the cytopenias, including immune and non-immune processes and, as in patients with chronic liver disease, splenic sequestration [11]. Liver disease, and thus portal hypertension, is, however, infrequent in SLE [12].

Splenomegaly does occur in SLE, and may be due to a response to demand for stem cell resources rather than portal hypertension. Hellmich et al. found that patients with SLE and neutropenia had a mean serum G-CSF level more than double that of SLE patients without neutropenia $(p=0.007)$ [26]. Elevation of serum G-CSF suggests, as in liver disease, both a demand for, and mobilization of, stem cells, with splenomegaly a consequence.

More extensive injury could be expected to generate greater demand for stem cell resources for repair. Splenomegaly in SLE patients does correlate with SLE disease activity, in that patients with more severe disease were found to have larger splenic volumes [55].

Again paralleling liver disease, patients with SLE may develop osteoporosis. The elevated serum G-CSF noted by Hellmich might contribute, at least in patients with sufficient stem cell demand to have chronic elevation of serum G-CSF [26]. In fact, Pineau et al. found that SLE patients with osteoporosis had significantly longer disease duration and greater SLE-related organ damage than those with normal bone density [30]. The lower bone density did not correlate with steroid use. It is thus possible that chronically elevated G-CSF in these individuals may result in loss of bone mass.

There may be downregulation of hematologic production in SLE as in liver disease. Pyrovolaki et al. have reported upregulation of apoptosis of hematopoietic progenitor cells in SLE patients [57]. Dainiak et al. noted suppression of hematopoietic precursors in bone marrow culture by SLE sera [33], paralleling the suppression of hematopoietic precursors in marrow culture by cirrhotic (and anemic) sera reported by Ohki [32]. The effect appears to be reversible; Dainiak reported a patient whose sera obtained during an SLE flare suppressed marrow culture, while sera obtained during a remission did not [33]. SLE can be treated with bone marrow transplantation where reduced disease activity (less auto injury) might result in reduced demand for stem cell resources for repair. Wang D. et al. reported significant increases in hemoglobin and platelet count in SLE patients following allogeneic mesenchymal stem cell transplantation [58].

Irradiated dogs and patients treated with chemotherapy have cytopenias attributable to reduced bone marrow stem cell resources. We have suggested that the cytopenias in liver disease may also reflect limited stem cell resources, due not to destruction of stem cells, but rather to diversion of stem cells to repair efforts. Cytopenias in patients with SLE may also reflect reduced stem cell resources due to repair efforts. Statkute et al. reported that SLE patients had significantly lower stem cell mobilization than patients with multiple sclerosis treated with the same mobilization regimen [59].

\section{Summary/Conclusions}

The contribution of bone marrow stem cells to the repair of organs was unknown at the time when Doan and Dameshek developed their theories to account for the association between liver disease, splenomegaly and cytopenias. The discovery that bone marrow contributes to organ repair has two relevant consequences. One, that there is a normal sequence of events in a response to a demand for stem cells; and two, that there may be competition for stem cell resources in the event of an injury.

The normal response to stem cell demand appears to include splenic enlargement as demonstrated in bone marrow stem cell donors, where G-CSF administration both mobilizes stem cells and causes splenic enlargement. That enlargement is not accompanied by a drop in platelet count, and in fact white blood cell counts increase, suggesting that cytopenias are not due to spleen size alone nor to G-CSF directly [6, 7]. The disconnect between spleen size and cytopenias is supported by the observation that splenomegaly persists after correction of cytopenias following liver transplant [10]. Additionally, spleen size does not correlate with portal venous pressure nor does decompression of the portal venous system either correct or prevent cytopenias $[5,8,9]$. These observations raise doubts as to sequestration being a full explanation of cytopenias in liver disease.

If spleen size is not altered by portal pressure in liver disease, then by what is it altered? The elevated serum G-CSF reported in two studies of patients with liver disease suggests an alternative, that splenic enlargement in liver disease is, as in bone marrow donors, part of the normal response to demand for stem cells [27, 28]. 
Concurrent splenomegaly and liver injury thus more likely reflect response to injury, rather than Doan's theory that increased portal venous pressure causes splenic enlargement and sequestration. Organ injury, splenomegaly and elevated G-CSF are also present in SLE, typically without liver disease [12, 26, 55]. This is further evidence in favor of splenic enlargement being a component of a response to injury, possibly mediated by GCSF, rather than an effect of portal pressure. If increased spleen size is a part of a normal response to demand for stem cells, and is not accompanied by cytopenias in normal individuals (bone marrow donors), then why do cytopenias occur in patients with liver disease or SLE?

Injury that triggers stem cell demand for organ repair will increase the total demand for bone marrow stem cells. Unless stem cell resources are infinite, this added demand might result in a need for prioritization. Experience with cancer patients and irradiated dogs indicates that stem cell resources are not infinite, and that low stem cell resources may be evidenced as cytopenias $[38,40]$. While decompressing the portal venous system does not reverse cytopenias, reducing stem cell demand by replacing an injured organ can do so, as in the case of liver transplantation [10, 22]. Similarly, reducing auto injury in SLE with bone marrow transplantation can reverse cytopenias [58].

If stem cell resources are finite, then non-repair uses for stem cells might be downregulated in the event of injury, an active process such as Dameshek envisioned. GCSF does inhibit bone production while mobilizing stem cells from bone marrow [31]. This suggests that repair efforts take priority, and thus it would be reasonable to expect downregulation of blood production, as Dameshek suggested. Studies of sera from patients with liver disease and those with SLE indicate that downregulation of hematopoiesis may occur [32, 33].

The above is neither intended to provide a comprehensive explanation of the cytopenias of liver disease and SLE, nor to try to simplify the interactions among bone marrow, spleen, and blood components. On the contrary, an active process would add complexity by suggesting that there is at least some contribution by a process not currently recognized. How much of a contribution to cytopenias an active suppression of hematopoiesis might make is unclear. Cytopenias are most likely multifactorial, and downregulation of hematopoiesis would more likely have identifiable effects in chronic rather than acute injury. Acute malaria causes liver injury with increased serum GCSF, yet hematologic abnormalities can be present within days of onset of symptoms, sooner than would be expected due to an altered rate of production [36, 60].

Cytopenias in SLE are likely to be particularly complex in nature. There are more than 100 autoantibodies reported in SLE, including autoantibodies to platelet glycoproteins thought to result in platelet destruction [61, 62]. In addition, Su et al. have reported that, "leucocyte apoptosis is significantly higher in SLE patients and correlates well with the levels of several autoantibodies" [63].

Although Dameshek may be correct in that there is an active process suppressing hematopoiesis, this does not mean that Doan's theory of sequestration is entirely incorrect. While evidence that portal pressure affects spleen size is lacking, blood components can be trapped in the spleen. Note that in primary immune thrombocytopenia, tagging platelets with Indium 111 often demonstrates platelet sequestration in the spleen, and that in this disease splenectomy can be effective in relieving thrombocytopenia [64].

On the whole, the current evidence does support Dameshek's theory that there is suppression of hematopoiesis, at least in some instances.

\section{Clinical implications}

The existence of an active signaling mechanism directing allocation of stem cell resources would raise the possibility for errors of that system. For example, over-suppression of hematologic production might account for some cases of cytopenias, notably those that occur following viral hepatitis [65].

Knowledge that a signaling mechanism may be in action directing the flow of stem cell resources could aid in the work-up of anemias. Evaluation of anemia in patients with SLE, liver disease or other chronic illness could include evaluation of stem cell demand, such as obtaining serum levels of IL-23 and G-CSF.

A signaling mechanism could also provide an opportunity for therapy. Rather than treating cytopenias in patients with liver disease by embolizing portions of the spleen, clinicians could seek agents that block the routing of stem cells to repair. This would have the disadvantage of reducing repair efforts, but would also offer the potential to lessen cytopenias without permanent damage to the spleen.

\section{Abbreviations}

ALT: Alanine transaminase; G-CSF: Granulocyte-colony stimulating factor; HCC: Hepatocellular carcinoma; IL-17: Interleukin 17; IL-23: Interleukin 23; INR: international normalized ratio; MELD: Mayo end-stage liver disease score; SLE: systemic lupus erythematosus; TIPS: transjugular intrahepatic portosystemic shunt; TPO: thrombopoietin; UNOS: United Network for Organ Sharing.

\section{Competing interests \\ None.}

\section{Authors' contributions}

JG organized the manuscript. Co-authors (AF, AS and EH) were all involved in drafting the manuscript and revising it critically for intellectual content. AF, AS and EH approved the final manuscript version submitted, and they are accountable for content. All authors read and approved the final manuscript.

\section{Acknowledgements}

The authors would like to thank Dan Deneen, Felixa Eskey, Bailey Johnston and Robyn Mosher for assistance with manuscript editing and preparation. 


\section{Received: 12 February 2015 Accepted: 20 January 2016}

\section{Published online: 09 February 2016}

\section{References}

1. Doan CA. Hypersplenism. Bull N Y Acad Med. 1949;25:625-50.

2. Dameshek W. Hypersplenism. Bull N Y Acad Med. 1955;31:113-36.

3. Crosby WH. Hypersplenism. Annu Rev Med. 1962;13:127-46.

4. Zakim D, Boyer TD, editors. Hepatology: A Textbook of Liver Disease. 4th ed. Philadelphia: Elsevier; 2003. p. 542-4.

5. Shah SH, Hayes PC, Allan PL, Nicoll J, Finlayson ND. Measurement of spleen size and its relation to hypersplenism and portal hemodynamics in portal hypertension due to hepatic cirrhosis. Am J Gastroenterol. 1996;91:2580-3.

6. Platzbecker U, Prange-Krex G, Bornhäuser M, Koch R, Soucek S, Aikele P, et al. Spleen enlargement in healthy donors during G-CSF mobilization of PBPCs. Transfusion. 2001;41:184-9.

7. Stroncek D, Shawker T, Follmann D, Leitman SF. G-CSF-induced spleen size changes in peripheral blood progenitor cell donors. Transfusion. 2003;43:609-13.

8. Mutchnick MG, Lerner E, Conn HO. Effect of portacaval anastomosis on hypersplenism. Dig Dis Sci. 1980;25:929-38.

9. Jabbour N, Zajko A, Orons P, Irish W, Fung JJ, Selby RR. Does transjugular intrahepatic portosystemic shunt (TIPS) resolve thrombocytopenia associated with cirrhosis? Dig Dis Sci. 1998;43:2459-62.

10. Eyraud D, Granger B, lonescu C, Fratéa S, Darnat S, Hannoun L, et al. Thrombocytopenia, splenomegaly, and portal blood flow in patients with liver transplants. Liver Transpl. 2011. doi: 10.1002/lt.22456.

11. Levine AB, Erkan D. Clinical assessment and management of cytopenias in lupus patients. Curr Rheumatol Rep. 2011;13:291-9.

12. Huang D, Aghdassi E, Su J, Mosko J, Hirschfield GM, Gladman DD, et al. Prevalence and risk factors for liver biochemical abnormalities in Canadian patients with systemic lupus erythematosus. J Rheumatol. 2012;39:254-61.

13. Pradella P, Bonetto S, Turchetto S, Uxa L, Comar C, Zorat F, et al. Platelet production and destruction in liver cirrhosis. J Hepatol. 2011;54:894-900.

14. Stockelberg D, Andersson P, Björnsson E, Björk S, Wadenvik H. Plasma thrombopoietin levels in liver cirrhosis and kidney failure. J Intern Med. 1999:246:471-5

15. Kitano K, Shimodaira S, Ito T, Ichikawa N, Kodaira H, Kohara Y, et al. Liver cirrhosis with marked thrombocytopenia and highly elevated serum thrombopoietin levels. Int J Hematol. 1999;70:52-5.

16. Kajihara M, Okazaki Y, Kato S, Ishii H, Kawakami Y, Ikeda Y, et al. Evaluation of platelet kinetics in patients with liver cirrhosis: similarity to idiopathic thrombocytopenic purpura. J Gastroenterol Hepatol. 2007;22:112-8.

17. Lindenbaum J, Lieber CS. Hematologic effects of alcohol in man in the absence of nutritional deficiency. N Engl J Med. 1969;281:333-8.

18. Huang HC, Huang YS, Wu JC, Tsay SH, Huo TI, Wang YJ, et al. Characteristics of autoimmune hepatitis in Taiwan: the 11 years' experiences of a medical center. Zhonghua Yi Xue Za Zhi (Taipei). 2002;65:563-9.

19. Onji M, Nonaka T, Horiike N, Moriwaki H, Muto Y, Ohta Y. Present status of autoimmune hepatitis in Japan. Gastroenterol Jpn. 1993:28 Suppl 4:134-8.

20. McCormick PA, Walker $S$, Benepal R. Hypersplenism is related to age of onset of liver disease. Ir J Med Sci. 2007;176:293-6.

21. Nash KL, Allison ME, McKeon D, Lomas DJ, Haworth CS, Bilton D, et al. A single centre experience of liver disease in adults with cystic fibrosis 1995-2006. J Cyst Fibros. 2008;7:252-7.

22. Coelho JC, Balbinot P, Nitsche R, Pinto KA, Parolin MB, Ivantes CA. Change in platelet count in patients with hypersplenism subjected to liver transplantation. Arq Gastroenterol. 2011;48:175-8.

23. Tutar NU, Isiklar I, Ulu EM, Haberal M. Spleen size changes in pediatric liver transplant recipients with functioning grafts. Transplant Proc. 2007;39:3199-201.

24. Yanaga K, Tzakis AG, Shimada M, Campbell WE, Marsh JW, Stieber AC, et al. Reversal of hypersplenism following orthotopic liver transplantation. Ann Surg. 1989;210:180-3.

25. Lemoli RM, Catani L, Talarico S, Loggi E, Gramenzi A, Baccarani U, et al. Mobilization of bone marrow-derived hematopoietic and endothelial stem cells after orthotopic liver transplantation and liver resection. Stem Cells. 2006;24:2817-25.

26. Hellmich B, Csernok E, de Haas M, von dem Borne AE, Schatz H, Gross WL, et al. Low Fcgamma receptor III and high granulocyte colony-stimulating factor serum levels correlate with the risk of infection in neutropenia due to Felty's syndrome or systemic lupus erythematosus. Am J Med. 2002;113:134-9.
27. Kaya AO, Coskun U, Sancak B, Buyukberber S, Yildiz R, Gulbahar O, et al. Increased serum granulocyte colony stimulating factor in Turkish hepatocellular carcinoma patients. Asian Pac J Cancer Prev. 2009;10:403-6.

28. Bazarniy W, Garenskikh NV. The diagnostic value of identification of granulocytic colony-stimulating factor under hepatocirrhosis]. Klin Lab Diagn. 2013;5:3-5 [Article in Russian].

29. Luxon BA. Bone disorders in chronic liver diseases. Curr Gastroenterol Rep. 2011;13:40-8.

30. Pineau CA, Urowitz MB, Fortin PJ, Ibanez D, Gladman DD. Osteoporosis in systemic lupus erythematosus: factors associated with referral for bone mineral density studies, prevalence of osteoporosis and factors associated with reduced bone density. Lupus. 2004;13:436-41.

31. Christopher MJ, Link DC. Granulocyte colony-stimulating factor induces osteoblast apoptosis and inhibits osteoblast differentiation. J Bone Miner Res. 2008;23:1765-74.

32. Ohki I, Dan K, Kuriya S, Nomura T. A study on the mechanism of anemia and leukopenia in liver cirrhosis. Jpn J Med. 1988;27:155-9.

33. Dainiak N, Hardin J, Floyd V, Callahan M, Hoffman R. Humoral suppression of erythropoiesis in systemic lupus erythematosus (SLE) and rheumatoid arthritis. Am J Med. 1980;69:537-44.

34. Theise ND, Nimmakayalu M, Gardner R, Illei PB, Morgan G, Teperman L, et al Liver from bone marrow in humans. Hepatology. 2000;32:11-6.

35. Eckersley-Maslin MA, Warner FJ, Grzelak CA, McCaughan GW, Shackel NA. Bone marrow stem cells and the liver: are they relevant? J Gastroenterol Hepatol. 2009;24:1608-16.

36. Stoiser B, Looareesuwan S, Thalhammer F, Daxböck F, Chullawichit S, ElMenyawi I, et al. Serum concentrations of granulocyte-colony stimulating factor in complicated Plasmodium falciparum malaria. Eur Cytokine Netw. 2000;11:75-80.

37. Kohno M, Shirabe K, Mano Y, Muto J, Motomura T, Takeishi K, et al. Granulocyte colony-stimulating-factor-producing hepatocellular carcinoma with extensive sarcomatous changes: report of a case. Surg Today. 2013:43:439-45.

38. Gertz MA. Current status of stem cell mobilization. Br J Haematol. 2010;150:647-62.

39. Canales MA, Fernández-Jiménez MC, Martín A, Arrieta R, Caballero MD, Díez J, et al. Identification of factors associated with poor peripheral blood progenitor cell mobilization in Hodgkin's disease. Haematologica. 2001;86:494-8.

40. Seed TM, Fritz TE, Tolle DV, Jackson 3rd WE. Hematopoietic responses under protracted exposures to low daily dose gamma irradiation. Adv Space Res. 2002:30:945-55.

41. Qamar AA, Grace ND, Groszmann RJ, Garcia-Tsao G, Bosch J, Burroughs AK, et al. Incidence, prevalence, and clinical significance of abnormal hematologic indices in compensated cirrhosis. Clin Gastroenterol Hepatol. 2009;7:689-95.

42. Stanca CM, Fiel MI, Aledort L, Cohen E, del Rio MJ, Schiano TD. Factors associated with persistent thrombocytopenia after liver transplantation. Transplant Proc. 2010;42:1769-73.

43. Dale DC, Bolyard AA, Schwinzer BG, Pracht G, Bonilla MA, Boxer L, et al. The Severe Chronic Neutropenia International Registry: 10-Year Follow-up Report. Support Cancer Ther. 2006;3:220-31.

44. Westerterp M, Gourion-Arsiquaud S, Murphy AJ, Shih A, Cremers S, Levine $\mathrm{RL}$, et al. Regulation of hematopoietic stem and progenitor cell mobilization by cholesterol efflux pathways. Cell Stem Cell. 2012;11:195-206.

45. El Husseiny NM, Fahmy HM, Mohamed WA, Amin HH. Relationship between vitamin D and IL-23, IL-17 and macrophage chemoattractant protein-1 as markers of fibrosis in hepatitis C virus Egyptians. World J Hepatol. 2012;4:242-7.

46. Sun HQ, Zhang JY, Zhang H, Zou ZS, Wang FS, Jia JH. Increased Th17 cells contribute to disease progression in patients with HBV-associated liver cirrhosis. J Viral Hepat. 2012;19:396-403.

47. Fábrega E, López-Hoyos M, San Segundo D, Casafont F, Pons-Romero F. Changes in the serum levels of interleukin-17/interleukin-23 during acute rejection in liver transplantation. Liver Transpl. 2009;15:629-33.

48. Qian C, Jiang T, Zhang W, Ren C, Wang Q, Qin Q, et al. Increased IL-23 and IL-17 expression by peripheral blood cells of patients with primary biliary cirrhosis. Cytokine+. 2013;64:172-80.

49. Zhao L, Tang Y, You Z, Wang Q, Liang S, Han X, et al. Interleukin-17 contributes to the pathogenesis of autoimmune hepatitis through inducing hepatic interleukin-6 expression. PLoS One. 2011;6:e18909.

50. Hayashi H, Beppu T, Masuda T, Mizumoto T, Takahashi M, Ishiko T, et al. Predictive factors for platelet increase after partial splenic embolization in liver cirrhosis patients. J Gastroenterol Hepatol. 2007;22:1638-42. 
51. Koconis $\mathrm{KG}$, Singh $\mathrm{H}$, Soares $\mathrm{G}$. Partial splenic embolization in the treatment of patients with portal hypertension: a review of the english language literature. J Vasc Interv Radiol. 2007;18:463-81.

52. Poulsom R, Forbes SJ, Hodivala-Dilke K, Ryan E, Wyles S, Navaratnarasah S, et al. Bone marrow contributes to renal parenchymal turnover and regeneration. J Pathol. 2001;195:229-35.

53. Zhao H, Li S, Yang R. Thrombocytopenia in patients with systemic lupus erythematosus: significant in the clinical implication and prognosis. Platelets. 2010;21(5):380-5.

54. Crispín JC, Tsokos GC. IL-17 in systemic lupus erythematosus. J Biomed Biotechnol. 2010;2010:943254

55. Harris AA, Kamishima T, Horita T, Atsumi T, Fujita N, Omatsu T, et al. Splenic volume in systemic lupus erythematosus. Lupus. 2009;18:1119-20.

56. Ziakas PD, Dafni UG, Giannouli S, Tzioufas AG, Voulgarelis M. Thrombocytopaenia in lupus as a marker of adverse outcome-seeking Ariadne's thread. Rheumatology (Oxford). 2006;45:1261-5.

57. Pyrovolaki K, Mavroudi I, Sidiropoulos P, Eliopoulos AG, Boumpas DT, Papadaki HA. Increased expression of CD40 on bone marrow CD34+ hematopoietic progenitor cells in patients with systemic lupus erythematosus: contribution to Fas-mediated apoptosis. Arthritis Rheum. 2009;60(2):543-52.

58. Wang D, Zhang H, Liang J, Li X, Feng X, Wang H, et al. Allogeneic mesenchymal stem cell transplantation in severe and refractory systemic lupus erythematosus: 4 years of experience. Cell Transplant. 2013;22(12):2267-77.

59. Statkute L, Verda L, Oyama Y, Traynor A, Villa M, Shook T, et al. Mobilization, harvesting and selection of peripheral blood stem cells in patients with autoimmune diseases undergoing autologous hematopoietic stem cell transplantation. Bone Marrow Transplant. 2007;39(6):317-29.

60. Leal-Santos FA, Silva SB, Crepaldi NP, Nery AF, Martin TO, Alves-Junior ER, et al. Altered platelet indices as potential markers of severe and complicated malaria caused by Plasmodium vivax: a cross-sectional descriptive study. Malar J. 2013; doi: 10.1186/1475-2875-12-462.

61. Eggert M, Zettl UK, Neeck G. Autoantibodies in autoimmune diseases. Curr Pharm Des. 2010;16:1634-43.

62. Jovancevic B, Lindholm C, Pullerits R. Anti B-cell therapy against refractory thrombocytopenia in SLE and MCTD patients: long-term follow-up and review of the literature. Lupus. 2013:22:664-74.

63. Su YJ, Cheng TT, Chen CJ, Chiu WC, Hsu CY, Chang WN, et al. The association among leukocyte apoptosis, autoantibodies and disease severity in systemic lupus erythematosus. J Transl Med. 2013;11:261.

64. Sarpatwari A, Provan D, Erqou S, Sobnack R, David Tai FW, Newland AC. Autologous $111 \mathrm{In}$-labelled platelet sequestration studies in patients with primary immune thrombocytopenia (ITP) prior to splenectomy: a report from the United Kingdom ITP Registry. Br J Haematol. 2010;151:477-87.

65. Gonzalez-Casas R, Garcia-Buey L, Jones EA, Gisbert JP, Moreno-Otero R. Systematic review: hepatitis-associated aplastic anaemia-a syndrome associated with abnormal immunological function. Aliment Pharmacol Ther. 2009;30:436-43.

\section{Submit your next manuscript to BioMed Central and we will help you at every step:}

- We accept pre-submission inquiries

- Our selector tool helps you to find the most relevant journal

- We provide round the clock customer support

- Convenient online submission

- Thorough peer review

- Inclusion in PubMed and all major indexing services

- Maximum visibility for your research

Submit your manuscript at www.biomedcentral.com/submit

CBiomed Central 